\title{
How does supply chain management affect financial performance? Evidence from coffee sector
}

\author{
Thu-Trang Thi Doan ${ }^{\mathrm{a}}$ and Toan Ngoc Bui ${ }^{\mathrm{a}}$
}

${ }^{a}$ Faculty of Finance and Banking, Industrial University of Ho Chi Minh City (IUH), Vietnam

\begin{tabular}{l}
\hline C H R O N I C L E \\
\hline Article history: \\
Received April 20, 2020 \\
Received in revised format June \\
8,2020 \\
Accepted June 102020 \\
Available online \\
June 142020 \\
\hline Keywords: \\
Coffee sector \\
Financial performance \\
Multiple regression analysis \\
Supply chain management \\
Vietnam
\end{tabular}

\section{Introduction}

Supply chain is a network between producers, suppliers and distributors to provide goods to consumers (Zigiaris, 2000; Sweeney, 2007; Janvier-James, 2012). It can be said that supply chain includes both external and internal relationships. Therefore, supply chain management can be defined as the management among its participants, including the relationships with suppliers, with intermediaries and distributors, and with customers (Chopra \& Meindl, 2001; Wahdan \& Emam, 2017). Supply chain management allows to supervise all processes including manufacture, purchase, transportation and distribution. The efficient supply chain management enables its participants to reduce cost, improve product quality (Aramyan et al., 2007; Habib, 2011; Waghmare \& Mehta, 2014; Wahdan \& Emam, 2017; Arifin et al., 2019), and more specially boost financial performance (Wahdan \& Emam, 2017). It can thus be admitted that supply chain management plays a major role for the success of its participants (Jones, 1998; Roekel et al., 2002). Hence, supply chain management has been more and more concerned by researchers and company managers (Van, 1998; Croom et al., 2000; Tan et al., 2002; Feldmann \& Müller, 2003). However, most of the previous scholars like Bui (2020a, 2020b, 2020c), Bui and Doan (2020), Doan and Bui (2020) have only examined financial performance of supply chain management in a general way or the relationship between finance supply chain and firm performance. A limited number of studies have investigated the impact of supply chain management on corporate performance (e.g. Li et al., 2006; Flynn et al., 2010) and competitive ability (e.g. Doan, 2020; Khaddam et al., 2020). In fact, there hardly exists a study considering the effect of supply chain management on financial performance of its participants despite the fact the latter is an important target which most companies try to achieve. This study is thus conducted to fill the literature gap by analyzing the impact of supply chain management on financial performance of the coffee companies. In Vietnam, the coffee industry is relatively nascent but has enormous potential for development. However, coffee companies are not able to achieve their full potential. One of the major reasons * Corresponding author

E-mail address: buingoctoan@iuh.edu.vn (T. N. Bui)

(C) 2020 by the authors; licensee Growing Science. doi: $10.5267 /$ j.uscm.2020.6.002 
for this limitation is the ineffective supply chain management in this sector. Therefore, the findings are expected to provide essential implications to the management in the coffee sector.

\section{Literature review and hypothesis development}

Supply chain can be understood as the interactions within a company and with external organizations such as partners, suppliers, and distributors (Zigiaris, 2000; Sweeney, 2007; Janvier-James, 2012; Wahdan \& Emam, 2017). Regarding supply chain management, it is the management of all elements of a supply chain (Chopra \& Meindl, 2001). At first, this term only mentioned the management of purchase and inventory. This has however been expanded to the management of all activities in supply chain, including sourcing, purchase, transportation, distribution and logistics (Janvier-James, 2012). Hence, supply chain is frequently measured through the relationships with suppliers, with intermediaries and distributors, and with customers (Khaddam et al., 2020). Supply chain management brings its participants significant benefits such as the cost reduction, the improvement in product quality (Aramyan et al., 2007; Habib, 2011; Waghmare \& Mehta, 2014; Wahdan \& Emam, 2017), and more importantly the improvement in financial performance (Wahdan \& Emam, 2017). Supply chain management is thus an approach many firms aim to, especially those in emerging economies (Roekel et al., 2002; Wahdan \& Emam, 2017). In regard to financial performance, this is a crucial target set by many companies (Yamin et al., 1999). Financial performance demonstrates the corporate growth over time (Holmberg, 2000), as well as plays a key role in supply chain (Li et al., 2006). Productivity, cost management and profitability are usually employed as proxies of financial performance (Wahdan \& Emam, 2017).

\subsection{Relationship with suppliers and financial performance}

One of the most essential activities of supply chain management is to maintain a long-lasting relationship with suppliers (Lamming, 1993; Balsmeier \& Voisin, 1996; Noble, 1997; Stuart, 1997; Monczka et al., 1998; Sheridan, 1998; Gunasekaran et al., 2001; Tan et al., 2002; Li et al., 2006). It is because a good relationship with suppliers enables the firm to perform better ( $\mathrm{Li}$ et al., 2006). In fact, a long-lasting relationship helps firms easily access to low-cost materials and become active in their manufacture and business, greatly contributing in enhancing the corporate financial performance. Therefore, the relationship with suppliers is anticipated to be a significant factor which is positively correlated to financial performance. Hypothesis $H_{1}$ : Relationship with suppliers (RS) positively affects financial performance (FP).

\subsection{Relationship with intermediaries and distributors and financial performance}

The relationship with intermediaries and distributors is established in order to boost operation ability of supply chain members as well as bring them lots of advantages (Balsmeier \& Voisin, 1996; Noble, 1997; Stuart, 1997; Monczka et al., 1998; Sheridan, 1998). In fact, many small companies can associate together to form a supply chain to participate in their common purchase, transportation and distribution, which helps decrease the cost and delivery time (Balsmeier \& Voisin, 1996), and also increase their benefits (Yoshino \& Rangan, 1995; Kumar et al., 2019). More than that, the participants can mutually share information (Monczka et al., 1998) which consists of that on both activities of material purchase and consuming market (Mentzer et al., 2000). Therefore, the companies can understand customers' demands and keep active in material sources, as well as raise the ability coping with unusual fluctuations in the market (Stein \& Sweat, 1998; Li et al., 2006). Hence, it can be said that the relationship between the company and its partners, specifically intermediaries and distributors is essential in the supply chain management and significant to the firm financial performance.

Hypothesis $\mathrm{H}_{2}$ : Relationship with intermediaries and distributors (RID) positively affects financial performance (FP).

\subsection{Relationship with customers and financial performance}

The relationship with customers includes all activities of solving customers' complaints, building a long-lasting relationship with customers, and improve customer satisfaction (Wines, 1996; Noble, 1997; Magretta, 1998; Claycomb et al., 1999; Day, 2000; Li et al., 2006). Admittedly, to manage the customer relationship is an important step in the supply chain management (Noble, 1997; Tan et al., 1998; Manab \& Aziz, 2019; Kermanian et al., 2019). Indeed, a well-maintained relationship with customers helps firms increase their competitive ability, improve customers' loyalty as well as obtain considerable benefits (Wines, 1996; Day, 2000). The management of customer relationship is thus essential in the supply chain management which exerts a positive influence on financial performance.

Hypothesis $\mathrm{H}_{3}$ : Relationship with customers (RC) positively affects financial performance (FP).

\section{Methodology}

Data are obtained by distributing a survey questionnaire to 248 company representatives of supply chain participants in the coffee sector in Vietnam in the third quarter of 2019. The paper investigates the effect of supply chain management on the coffee firms' financial performance in Vietnam. The Cronbach's Alpha test and Exploratory Factor Analysis (EFA) are adopted to determine the valid factors for the research model. Then, the multiple regression analysis is employed for the 
estimation. The model is developed following the relevant studies' findings and hypotheses. In specific, financial performance is chosen as the dependent variable. The independent variables indicating for supply chain management comprise relationship with suppliers (RS), relationship with intermediaries and distributors (RID) and relationship with customers (RC).

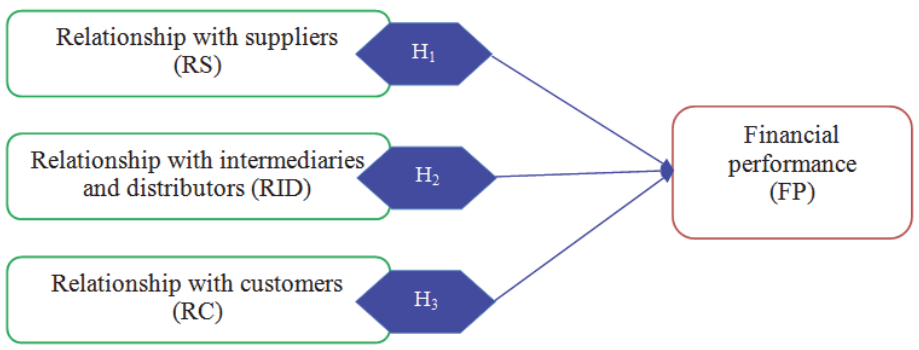

Fig. 1. The suggested research model

\section{Empirical results}

First, the Cronbach's Alpha test is performed to all variables in the model. The results are presented in Table 1 as follows:

Table 1

Results of Cronbach's Alpha test

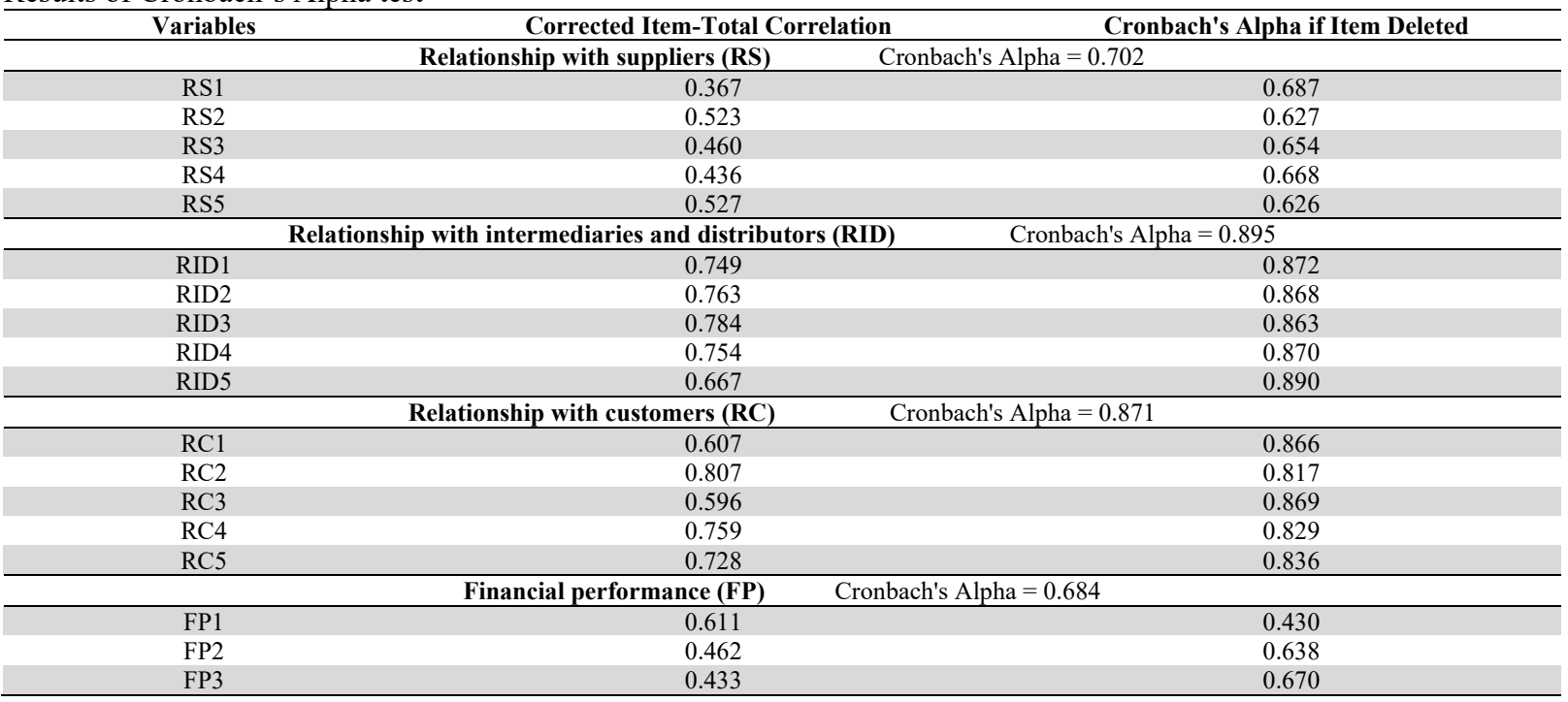

Table 1 reveals that the coefficient alpha and corrected item - total correlation of all variables are valid.

Table 2

Results of Explanatory Factor Analysis (EFA)

\begin{tabular}{|c|c|c|c|c|}
\hline \multirow{2}{*}{\multicolumn{2}{|c|}{ Variables }} & \multicolumn{3}{|c|}{ Component } \\
\hline & & 1 & 2 & 3 \\
\hline \multirow{5}{*}{ Relationship with intermediaries and distributors (RID) } & RID3 & 0.868 & & \\
\hline & RID2 & 0.848 & & \\
\hline & RID4 & 0.840 & & \\
\hline & RID1 & 0.835 & & \\
\hline & RID5 & 0.768 & & \\
\hline \multirow{5}{*}{ Relationship with customers (RC) } & $\mathrm{RC} 2$ & & 0.892 & \\
\hline & $\mathrm{RC} 4$ & & 0.861 & \\
\hline & RC5 & & 0.817 & \\
\hline & $\mathrm{RC} 1$ & & 0.746 & \\
\hline & $\mathrm{RC} 3$ & & 0.719 & \\
\hline \multirow{5}{*}{ Relationship with suppliers (RS) } & RS5 & & & 0.743 \\
\hline & RS2 & & & 0.723 \\
\hline & RS3 & & & 0.678 \\
\hline & RS4 & & & 0.649 \\
\hline & RS1 & & & 0.592 \\
\hline Kaiser-Meyer-Olkin Measure of Sampling Adequacy & & \multicolumn{3}{|c|}{0.824} \\
\hline Bartlett's Test of Sphericity (Sig.) & & \multicolumn{3}{|c|}{$0.000^{* * *}$} \\
\hline Cumulative \% & & \multicolumn{3}{|c|}{61.915} \\
\hline Eigenvalue & & \multicolumn{3}{|c|}{2.273} \\
\hline
\end{tabular}


Table 2 shows that the indices of the Explanatory Factor Analysis are all appropriate. It can thus be concluded that three indicators of supply chain management which are relationship with suppliers (RS), relationship with intermediaries and distributors (RID), and relationship with customers (RC) may be associated with financial performance (FP).

Table 3

Results of the model estimation

\begin{tabular}{lcc}
\hline Dependent Variable: Financial performance (FP) & Coef. & Sig. \\
\hline Variable & $0.659^{* * * *}$ & 0.000 \\
\hline Relationship with intermediaries and distributors (RID) & $0.588^{* * *}$ & 0.000 \\
Relationship with customers (RC) & $0.491^{* * *}$ & 0.000 \\
Relationship with suppliers (RS) & & 248 \\
N & & $0.000^{* * *}$ \\
ANOVA (sig.) & & $79.2 \%$ \\
R Square & &
\end{tabular}

Table 2 demonstrated the results of the model estimation. Accordingly, the results are significant at the $1 \%$ level. R-squared is $79.2 \%$, which represents that the independent variables can account for $79.2 \%$ of variation in financial performance. It can be deduced that supply chain management exerts a significant effect on financial performance of coffee companies in Vietnam. This is in line with what was reported by Wahdan et al. (2017). However, the study greatly succeeds in revealing the significant relationship between the indicators of supply chain management and financial performance. This is also the unprecedented finding of this study.

Indeed, at the $1 \%$ level of significance, financial performance (FP) is positively affected by three determinants including relationship with intermediaries and distributors (RID), relationship with customers (RC), relationship with suppliers (RS). Based on this, the estimated results take the following equation:

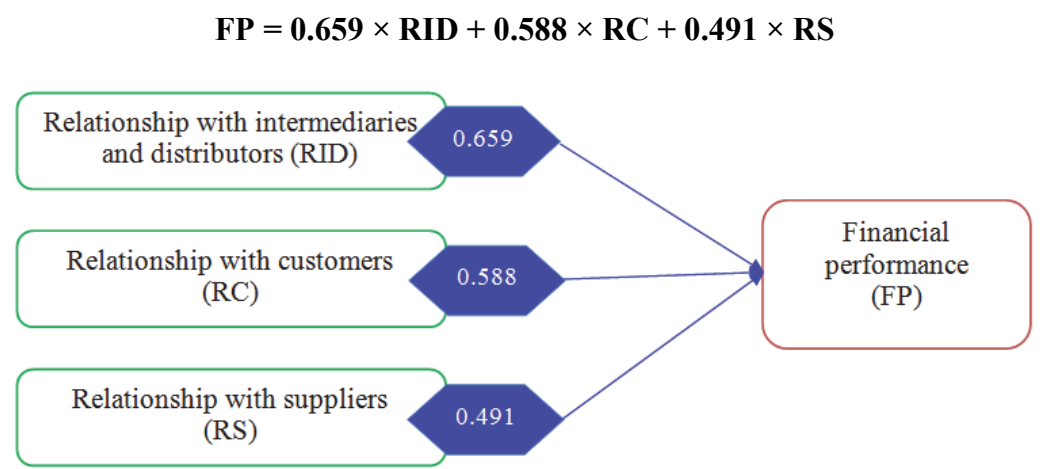

Fig. 2. Results of the model estimation

-The impact of relationship with intermediaries and distributors on financial performance: The findings show that the relationship with intermediaries and distributors (RID) is positively $(\beta=0.659)$ correlated to financial performance (FP). It can be concluded that relationship with intermediaries and distributors plays a crucial role in boosting the corporate financial performance in supply chain. This is right to the fact that it requires a big number of intermediaries and distributors for the coffee industry. If this relationship can last long and effectively, the entire supply chain can receive substantial benefits. Then, the member companies can link together to mutually participate in purchase, transportation and distribution. Further, it is easier for them to share information on input and output markets. Thanks to this, they can reduce the cost, transportation time, and most notably enhance the financial performance.

- The impact of relationship with customers on financial performance: The results report the positive influence ( $\beta=$ 0.588) of relationship with customers (RC) on financial performance (FP). Accordingly, the relationship with customers is a major driver of supply chain management which helps supply chain participants improve their financial performance. Indeed, a long-lasting customer relationship enables the members to retain their current customers and attract more potential customers. This makes supply chain perform more efficiently, and more specially boosts the financial performance of its participants.

- The impact of relationship with suppliers on financial performance: The results show that relationship with suppliers (RS) exerts a positive effect $(\beta=0.491)$ on financial performance (FP). It is admitted that that the relationship with suppliers is maintained long will bring more advantages to the firms participating in supply chain, and specially enhance their financial performance. Indeed, they can stably access to stable material sources at a low price, which helps them active in the manufacture and business, thereby boosting the financial performance. Particularly to the coffee industry, intermediaries and producers often compete fiercely in the purchase. Therefore, it is really important to maintain a long-lasting relationship with suppliers in order to ensure a stable input source in high quality. 


\section{Conclusion}

The study has considered the effect of supply chain management on the corporate financial performance in Vietnam's coffee sector. By this objective, the multiple regression analysis has been adopted to estimate the model. The results have revealed that financial performance was positively related to relationship with intermediaries and distributors, relationship with customers, and relationship with suppliers. In particular, relationship with intermediaries and distributors is the most significant driver of financial performance. The results are first empirical evidence on the impact of supply chain management on financial performance of Vietnamese coffee companies. They are thus essential to Vietnam, especially to coffee company managers. According to them, to enhance the financial performance, the coffee firms should pay more attention on improving supply chain. The improvement in supply chain does not only include the internal improvement but also more concern about the relationships with suppliers, customers, and more specially intermediaries and distributors.

\section{References}

Aramyan, L., Lansink, A. O., Van, J. D. V., \& Van, O. K. (2007). Performance measurement in agri-food supply chains: A case study. Supply Chain Management: An International Journal, 12(4), 304-315.

Arifin, M., Ibrahim, A., \& Nur, M. (2019). Integration of supply chain management and tourism: An empirical study from the hotel industry of Indonesia. Management Science Letters, 9(2), 261-270.

Balsmeier, P. W., \& Voisin, W. (1996). Supplychain management: A time based strategy. Industrial Management, 38(5), 24-7.

Bui, T. N. (2020a). How does corporate performance affect supply chain finance? Evidence from logistics sector. Uncertain Supply Chain Management, 8(3), 563-568.

Bui, T. N. (2020b). How do financial leverage and supply chain finance influence firm performance? Evidence from construction sector. Uncertain Supply Chain Management, 8(2), 285-290.

Bui, T. N. (2020c). Supply chain finance, financial development and profitability of real estate firms in Vietnam. Uncertain Supply Chain Management, 8(1), 37-42.

Bui, T. N., \& Doan, T. T. T. (2020). Factors influencing supply chain finance of real estate sector: Evidence using GMM estimation. Uncertain Supply Chain Management, 8(3), 627-632.

Chopra, S., \& Meindl, P. (2001). Supply Chain Management: Strategy, Planning, and Operations. Prentice-Hall, Inc., Upper Saddle River, NJ.

Claycomb, C., Droge, C., \& Germain, R. (1999). The effect of just in time with customers on organizational design and performance. International Journal of Logistics Management, 10(1), 37-58.

Croom, S., Romano, P., \& Giannakis, M. (2000). Supply chain management: an analytical framework for critical literature review. European Journal of Purchasing and Supply Management, 6(1), 67-83.

Day, G. S. (2000). Managing market relationships. Journal of the Academy of Marketing Science, 28(1), 24-30.

Doan, T. T. T. (2020). Supply chain management drivers and competitive advantage in manufacturing industry. Uncertain Supply Chain Management, 8(3), 473-480.

Doan, T. T. T., \& Bui, T. N. (2020). Nonlinear impact of supply chain finance on the performance of seafood firms: A case study from Vietnam. Uncertain Supply Chain Management, 8(2), 267-272.

Feldmann, M., \& Müller, S. (2003). An incentive scheme for true information providing in supplychains. $O M E G A$, 31(2), 63-73.

Flynn, B. B., Huo, B., \& Zhao, X. (2010). The impact of supply chain integration on performance: A contingency and configuration approach. Journal of Operations Management, 28, 58-71.

Gunasekaran, A., Patel, C., \& Tirtiroglu, E. (2001). Performance measures and metrics in a supplychain environment. International Journal of Operations and Production Management, 21(1/2), 71-87.

Habib, M. (2011). Supply Chain Management (SCM): Theory and Evolution, Supply Chain Management - Applications and Simulations. Prof. Dr. Md. Mamun Habib (Ed.), ISBN: 978-953-307250-0, InTech.

Holmberg, S. (2000). A systems perspective on supply chain measurements. International Journal of Physical Distribution and Logistics Management, 30(10), 847-868.

Janvier-James, A. M. (2012). A new introduction to supply chains and supply chain management: Definitions and theories perspective. International Business Research, 5(1), 194-207.

Jones, C. (1998). Moving beyond ERP: making the missing link. Logistics Focus, 6(7), 2-7.

Kermanian, M., Rafiei, S., Keyvanfar, H., \& Sadi-Nezhad, S. (2019). Corporate Governance: A scientometric analysis. Accounting, 5(4), 153-168.

Khaddam, A. A., Irtaimeh, H. J., \& Bader, B. S. (2020). The effect of supply chain management on competitive advantage: The mediating role of information technology. Uncertain Supply Chain Management, 8(3), 547-562.

Kumar, A., Garg, R., \& Garg, D. (2019). An empirical study to identify and develop constructive model of e-supply chain risks based on Indian mechanical manufacturing industries. Management Science Letters, 9(2), 217-228.

Lamming, R. (1993). Beyond partnership: strategies for innovation and lean supply. New York: Prentice-Hall.

Li, S., Ragu-Nathan, B., Ragu-Nathan, T. S., \& Rao, S. S. (2006). The impact of supply chain management practices on competitive advantage and organizational performance. Omega, 34, 107-124 
Magretta, J. (1998). The power of virtual integration: an interview with Dell computers'Michael Dell. Harvard Business Review, 76(2), 72-84.

Manab, N., \& Aziz, N. (2019). Integrating knowledge management in sustainability risk management practices for company survival. Management Science Letters, 9(4), 585-594.

Mentzer, J. T., Min, S., \& Zacharia, Z. G. (2000). The nature of inter-firm partnering in supplychain management. Journal of Retailing, 76(4), 549-568.

Monczka, R. M., Petersen, K. J., Handfield, R. B., \& Ragatz, G. L. (1998). Success factors in strategic supplier alliances: the buying company perspective. Decision Science, 29(3), 553-577.

Noble, D. (1997). Purchasing and supplier management as a future competitive edge. Logistics Focus, 5(5), 23-27.

Roekel, J. V, Willems, S., \& Boselie, D. M. (2002). Agri-Supply Chain Management To Stimulate Cross-Border Trade in Developing Countries and Emerging Economies. Washington, DC: World Bank.

Sheridan, J. H. (1998). The supply-chain paradox. Industry Week, 247(3), 20-29.

Stein, T., \& Sweat, J. (1998). Killer supplychains. Informationweek, 708(9), 36-46.

Stuart, F. I. (1997). Supply-chain strategy: organizational influence through supplier alliances. British Academy of Management, 8(3), 223-236.

Sweeney, E. (2007). Understanding Supply Chain Management. In Perspectives on Supply Chain Management and Logistics - Creating Competitive Organisations in the 21st Century (Sweeney, E. ed). Chapter 3 (pp. 27-72). Dublin: Blackhall Publishers.

Tan, K. C., Kannan, V. R., \& Handfield, R. B. (1998). Supplychain management: supplier performance and firm performance. International Journal of Purchasing and Materials Management, 34(3), 2-9.

Tan, K. C., Lyman, S. B., \& Wisner, J. D. (2002). Supply chain management: a strategic perspective. International Journal of Operations and Production Management, 22(6), 614-631.

Van, H. R. I. (1998). Measuring the unmeasurable - measuring and improving performance in the supply chain. Supply Chain Management, 3(4), 187-192.

Waghmare, M. P., \& Mehta, M. B. (2014). Information Technology and Supply Chain Management Practices in Global Business Organizations - A Study. IBMRD's Journal of Management \& Research, 3(2), 107-112.

Wahdan, M. A., \& Emam, M. A. (2017). The impact of supply chain management on financial performance and responsibility accounting: Agribusiness case from Egypt. Accounting and Finance Research, 6(2), 136-149.

Wines, L. (1996). High order strategyfor manufacturing. The Journal of Business Strategy, 17(4), 32-33.

Yamin, S., Gunasekaran, A., \& Mavondo, F. T. (1999). Relationship between generic strategies, competitive advantage and organizational performance: an empirical analysis. Technovation, 19(8), 507-518.

Yoshino, M., \& Rangan, S. (1995). Strategic alliances: an entrepreneurial approach to globalization. Boston, MA: Harvard Business School Press.

Zigiaris, S. (2000). Supply Chain Management. Report produced for EC funded project, 1-27.

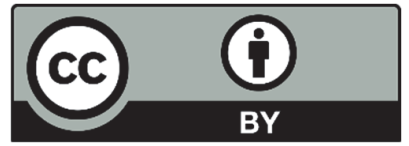

(C) 2020 by the authors; licensee Growing Science, Canada. This is an open access article distributed under the terms and conditions of the Creative Commons Attribution (CC-BY) license (http://creativecommons.org/licenses/by/4.0/). 